This document is confidential and is proprietary to the American Chemical Society and its authors. Do not copy or disclose without written permission. If you have received this item in error, notify the sender and delete all copies.

\title{
Is traffic still an important emitter of mono-aromatic organic compounds in European urban areas?
}

\begin{tabular}{|r|l|}
\hline Journal: & Environmental Science \& Technology \\
\hline Manuscript ID & es-2017-01408s.R2 \\
\hline Manuscript Type: & Article \\
\hline Date Submitted by the Author: & n/a \\
\hline Complete List of Authors: & $\begin{array}{l}\text { BORBON, Agnès; CNRS, Laboratoire de Météorologie Physique LaMP/CNRS } \\
\text { Boynard, Anne; LATMOS Site de Paris } \\
\text { Salameh, Therese; IMT Lille Douai } \\
\text { Baudic, Alexia; AIRPARIF } \\
\text { Gros, Valerie; Institut Pierre Simon Laplace } \\
\text { Gauduin, Julie; AIRPARIF } \\
\text { Perrussel, Olivier; AIRPARIF } \\
\text { Pallares, Cyril; ATMOS ALSACE }\end{array}$ \\
\hline
\end{tabular}

\section{SCHOLARONE ${ }^{m}$ \\ Manuscripts}


1 Is traffic still an important emitter of mono-aromatic organic 2 compounds in European urban areas?

3

4

5

6

7

8

9

10

11

12

13

14

15

Agnès Borbon ${ }^{1 *}$, Anne Boynard ${ }^{2}$, Thérèse Salameh ${ }^{3 \dagger}$, Alexia Baudic ${ }^{4,5}$ Valérie Gros ${ }^{4}$, Julie Gauduin ${ }^{5}$, Olivier Perrussel ${ }^{5}$, Cyril Pallares $^{6}$

1. Université Clermont Auvergne, CNRS, LaMP, F-63000 Clermont-Ferrand, France

2. LATMOS/IPSL, UPMC Univ. Paris 06 Sorbonne Universités, UVSQ, CNRS, Paris, France

3. Laboratoire Inter-Universitaire des Systèmes Atmosphériques (LISA), UMR CNRS 7583, Université Paris Est Créteil et Université Paris Diderot, Institut Pierre Simon Laplace, Créteil, France

4. Laboratoire des Sciences du Climat et de l'Environnement (LSCE), UMR CNRS 8212, Commissariat à l'Energie Atomique et aux énergies alternatives, Université Versailles Saint-Quentin, Institut Pierre-Simon Laplace, Gif sur Yvette, France.

5. AIRPARIF, Association Agréée de Surveillance de la Qualité de l'Air en Île-deFrance, 75004 Paris, France

6. Agence de surveillance de la qualité de l'air (ASPA), F-67300, Schiltigheim, France

${ }^{\ddagger}$ now at: IMT Lille Douai, Univ. Lille, SAGE - Département Sciences de l'Atmosphère et Génie de l'Environnement, 59000 Lille, France

* corresponding author a.borbon@opgc.univ-bpclermont.fr 


\section{Abstract}

Trends of long-term observations and emission inventories suggest that traffic emissions will no longer dominate the concentrations of mono-aromatic compounds (i.e. TEX - Toluene, Xylenes and Ethylbenzene) in European urban areas. But the split limit between traffic and other emission sector contributions such as solvent use remains tenuous. Here long-term observations of an extensive set of hydrocarbons, including TEX, at traffic and urban background sites in London, Paris and Strasbourg were combined to estimate the relative importance of traffic emissions on TEX in every city. When analyzing the urban enhancement emission ratios of TEX-to-benzene on a seasonal basis, two potential source signatures other than traffic could be differentiated in all cities (1) summertime evaporation from fuel and/or solvent and (2) wintertime domestic heating. However, traffic emissions still unambiguously dominate the concentration levels of TEX in every city despite the reduction of their emissions at exhaust pipe over the last two decades. Traffic explains between $60 \%$ and $96 \%$ (at $\pm 20 \%$ ) of TEX levels while it is less clear for xylenes at some locations. Our results provide a basis to evaluate regional emission inventories. The method is applicable at any urban area where speciated hydrocarbon monitoring is available.

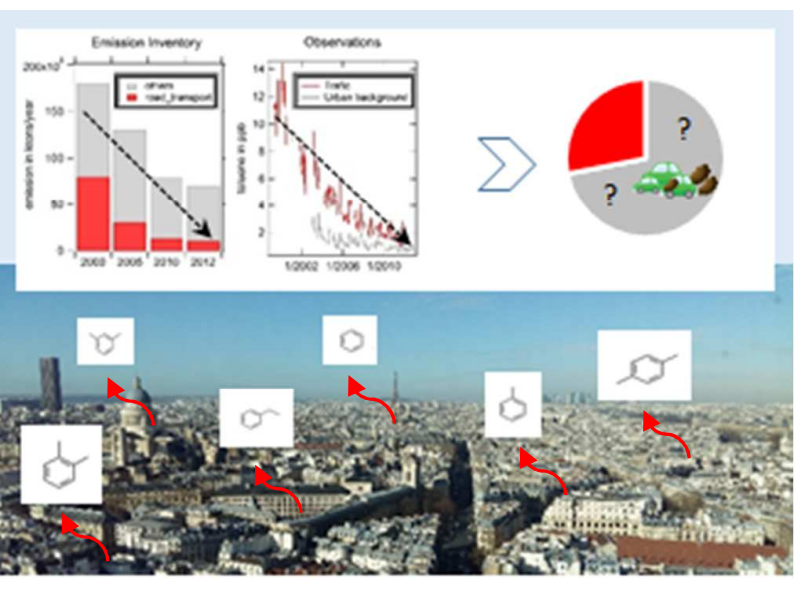

Toc Art 
40

41

42

43

44

45

46

47

51

52

\section{Key points:}

- Emission inventories and multi-year trends of long-term observations raise the question of the impact of traffic emissions on TEX concentration levels in European urban areas

- One decade of hourly observations of hydrocarbons at traffic and urban stations in Paris, London and Strasbourg is used to estimate the traffic fraction of TEX concentrations

- The seasonal signature of TEX sources is rather due to seasonal changes in traffic emission composition and additional wintertime domestic combustion for benzene

- It is demonstrated that traffic emissions still account for more than $60 \%$ of most TEX concentrations regardless of the season while is less clear for xylenes at some urban locations 


\section{Introduction}

BTEX (Benzene, Toluene, Ethylbenzene and $(\mathrm{m}+\mathrm{p})$ and o-Xylenes), a sub-group of Volatile Organic Compounds (VOC), still constitute a significant fraction of VOCs in urban atmospheres up to $47 \%$ in volume of total Non-Methane Hydrocarbons (NMHC) after $\mathrm{C}_{2}$ $\mathrm{C}_{9}$ alkanes ${ }^{1 ; 2 ; 3 ; 4,5}$. BTEX are released into the atmosphere by either fossil fuel related emission sources (transport, storage and distribution of fossil fuels, industrial and residential combustion, processes) and solvent use ${ }^{6}$. For only benzene, which is known to be carcinogenic $^{7}$, the European air quality objective for health protection of $5 \mu \mathrm{g} \cdot \mathrm{m}^{-3}(1.57 \mathrm{ppb}$ STP) per year is still exceeded in the center of Paris close to major roadways ${ }^{8}$. Apart from their abundance and adverse health effects, BTEX have significant implications on atmospheric chemistry. Together with alkenes, they show the highest ozone-forming potential $^{9,10}$. They have therefore been considered as key target compounds by ozone policy reduction measures, especially in urban areas where ozone is usually VOC-limited ${ }^{11}$. BTEX oxidation also contributes to the formation of Secondary Organic Aerosols (SOA). While high uncertainties persist on SOA yields depending on smog-chamber experimental conditions, BTEX show SOA yields as significant as the one of $\alpha$-pinene, the most emitted and reactive biogenic precursor being currently the dominant SOA source at the global scale: yield values range from 1181 (benzene) to $1578 \mu \mathrm{g} \cdot \mathrm{m}^{-3} \cdot \mathrm{ppm}^{-1}$ (xylenes), respectively ${ }^{12,13}$ against $1826 \mu \mathrm{g} \cdot \mathrm{m}^{-3} \cdot \mathrm{ppm}^{-1}$ for $\alpha$-pinene ${ }^{14}$. Recent results have suggested that BTEX could explain $34 \%$ of SOA production in summer ${ }^{15}$ in Paris megacity whereas such a contribution would be lower when taking into account a larger set of VOC of intermediate volatility (IVOC) in Los Angeles ${ }^{16}$. Like terpenes, oxidation of mono-aromatics would also lead to the rapid formation of highly oxygenated molecules as recently suggested by Molteni and coworkers ${ }^{17}$. 
VOC emission reduction measures, such as emission reduction at vehicle exhaust pipe, have successfully reduced their anthropogenic concentrations in cities like London ${ }^{18}$, Paris and other medium-sized cities in France ${ }^{6}$, Los Angeles ${ }^{19}$ and at rural stations ${ }^{20,6}$. The multi-year trends of monthly average concentrations of toluene (Figure 1) and other aromatics (Figures S1, S2, S3 in Supplement Information) at both urban background and traffic sites in three European metropolitan areas (London, Paris and Strasbourg) support these findings. Regardless of the city, all concentrations have consistently shown a clear decline at traffic sites since 2000, especially in the first half of the decade. However, aromatic levels at urban background sites have stayed almost constant since 2008 and concentrations at traffic sites tend towards the urban background levels. This raises the question whether traffic emissions still dominate TEX emissions. Up-to-date emission inventories in all three cities (see piecharts on the right hand panel of Figure 1 and Figures S1 to S3 in SI) show various features. It should be noted that no local emission inventory is available for London megacity and the emission distribution is adapted from the National Atmospheric Emission Inventory in UK (NAEI) for the year 2000 (D. Derwent and S. Beevers' personal communication). For toluene, the road-transport sector accounts for half of its emissions in London and Paris and only $10 \%$ in Strasbourg. For xylenes (Figures S1 and S2), the road-transport contribution drops down to 4\%-33\% except for o-xylene in London (57\%). The solvent use and/or residential sector appear as the other major source explaining between $28 \%$ and $56 \%$ of toluene emissions and 44 to $77 \%$ especially for xylenes. Only ethylbenzene would be still largely emitted by the road-transport sector $(44-68 \%$ ) (see Figure S3). Regional emission inventories for two European cities, Paris and Zurich in 2005, also pointed to the use of solvents from all source categories as the new dominant source of total VOCs at the urban scale. Finally, the homogeneity of aromatic multi-year trends depicted in observations is not reflected in regional emission inventories. However emission inventories for VOCs still show high 
101 uncertainties up to a factor of $4^{21}$ and observations provide useful constraints for their 102 evaluation $22 ; 23$ 24; 21;25. Source-receptor models like PMF (Positive Matrix Factorization) 103 usually point to the contribution of various sources to total measured VOC ambient levels ${ }^{26 ; 27}$;

10424 . BTEX usually show significant contributions in the source profiles of vehicle exhaust, 105 solvent use-related activities and wood combustion for benzene ${ }^{26,27,24,28}$. Mathematics 106 supporting source-receptor models directly imply an estimation of source/factor contributions 107 to total measured VOC concentrations rather than individual species. Towards the complexity 108 of TEX emission sources, there is still no consensus on the importance of BTEX source and 109 for traffic in particular. Moreover, the seasonality of emission changes has been poorly 110 studied for BTEX.

111 In this study, we combine long-term and continuous in-situ measurements of NMHC, 112 including BTEX, carried out in European urban areas by air quality monitoring network 113 programs over the past decade to investigate the importance of traffic emissions on mono114 aromatic levels at the urban scale. Due to its stringent regulation in fossil fuel and solvent 115 formulation compared to other mono-aromatic compounds, benzene will be treated here as a 116 combustion source tracer rather than a target species for the quantification of traffic 117 contribution. This study provides a scientific basis to evaluate the accuracy of regional 118 emission inventories.

\section{Experimental}

120 Data analysis mostly relies on continuous hourly observations of a large set of NMHC, 121 including BTEX, performed by European air quality networks in the megacities of London 122 (UK by DEFRA), Paris (France by AIRPARIF) and Strasbourg (Eastern France by ASPA). 123 The chosen period for data analysis covers the years 2008 to 2013. Special care was put on 124 data quality checks. The description of quality assurance tests is provided in Boynard et al. 
$125(2014)^{2}$ and Waked et al. (2016) ${ }^{6}$ for French data and Dollard et al. (2007) ${ }^{29}$ for UK data. The 126 purpose here is to evaluate the importance of traffic emissions relative to other anthropogenic 127 emissions. Data analysis has therefore combined observations collected at both traffic and 128 urban background sites in each city to provide perspectives from contrasted urban situations 129 non-influenced by industrial emissions. Traffic sites represent those locations under the direct 130 influence of nearby traffic emissions, usually a roadway tolerating traffic greater than 10,000 131 vehicles per day. Urban background sites are under the influence of multi-emitters, at a 132 distance of major traffic lanes of $40 \mathrm{~m}$ on average and are more likely representative of the 133 urban mixing of all anthropogenic emissions. Details on the database are reported in Table 1. 134 A description of the sites, meteorology and analytical devices is provided in the Supplement Information (pages S5-S6). Note that the Paris data has been completed by tunnel measurements performed during the PREQUALIF project ${ }^{28}$. The number of missing data is usually lower than $25 \%$ over the six-year period.

138 Results and discussion

\section{Concentration levels of BTEX}

147 level to achieve the air quality standard of $5 \mu \mathrm{g} . \mathrm{m}^{-3}$ per year by, for instance, limiting its

Average concentration levels of mono-aromatics including benzene in the three metropolitan areas are reported in Table S1 ( $2^{\text {nd }}$ to $5^{\text {th }}$ column) in the Supplement Information for the year 2011. BTEX concentration levels range between $0.03 \mathrm{ppb}$ (ethylbenzene at Strasbourg Ouest and 1,74 ppb (toluene at Paris-Auteuil), i.e. two orders of magnitude. Concentration levels are 2 to 4 times higher at the traffic sites compared to urban background sites. Concentrations of benzene are quite similar between the three cities at $\pm 0.040 \mathrm{ppb}$ at traffic sites and $\pm 0.070 \mathrm{ppb}$ at urban background sites. This is consistent with its stringent regulation policy at European presence at 1\% vol. in fuels (Directives 98/70/EC replace by 2009/30/EC and 2003/17/EC). 
149 On the opposite, the sum of BTEX load is higher in Paris by 1.4 at traffic sites to 2.4 at urban

150 background sites while concentration levels in London and Strasbourg are surprisingly quite

151 comparable. However, the atmospheric composition in BTEX is very similar between near-

152 traffic and urban background atmospheres. Together with $(\mathrm{m}+\mathrm{p})$-xylenes, toluene (which is

153 the dominant species among BTEX) explains 70\% of BTEX load. This suggests that BTEX

154 concentrations are driven by emissions with a non-visible effect of photochemical processing

155 at the background sites. For the latter we would have expected an enrichment of air mass

156 composition in longer-lived mono-aromatics like benzene given that BTEX reactivity towards

$157 \mathrm{OH}$ radical spans one order of magnitude ${ }^{30}$. For benzene, a domestic heating source is highly 158 suspected, especially in Strasbourg (see following sections) and as recently shown by Baudic 159 and co-workers ${ }^{28}$.

Seasonal source signature on TEX

161 The magnitude of TEX concentrations is affected by the proximity of emission sources, the 162 extent of photochemical processes and boundary layer conditions. To minimize those effects, we use the TEX-to-benzene enhancement emission ratio $(\mathrm{ER}=\Delta[\mathrm{TEX}] / \Delta[$ benzene $])$ at urban background sites to identify the TEX source signature on a seasonal basis in order to index seasonal changes in urban enhancement ratios to potential changes in the nature and intensity of their sources. The TEX-to-benzene enhancement ratio equals the slope of a linear 2-sided

167 fit of a TEX-to-benzene correlation plot. An illustration of summertime (July) and wintertime 168 (January) scatterplots is provided in Figure 2a over the six-year period at the urban background sites. Urban enhancement ER of toluene-to-benzene representative of traffic, domestic wood combustion and gasoline evaporation emissions are also reported to provide a

171 comparison basis, which is rather qualitative than quantitative regarding the numerous factors 172 modifying the emission composition. These three emission categories have been usually 
173 identified as TEX major sources in urban areas ${ }^{21 ; 24 ; 28}$. The determination of the reported 174 values of ER is described in the Supplement Information (pages S7-S8). Emissions from 175 solvent use cannot be excluded but representative ER relative to benzene can hardly be 176 determined. The main reason is due to the diversity of solvents. Speciated emission profiles 177 usually show great variability with, for instance, toluene-to-benzene ratios spanning two 178 orders of magnitude ${ }^{31}$. Moreover, benzene, due to its toxic and carcinogen nature, has been 179 strongly limited in solvent formulations. Current standards in Europe have established limits 180 in benzene at $0.1 \%$ in cleaning products.

181

Remarkably, scatterplots show similar multiform patterns in all urban areas (Figure 2a). The scatterplots lie within a domain delimited by the evaporative source ER in its upper part and the domestic wood combustion ER in its lower part. Within these limits, the wintertime and summertime scatterplots roughly split along the traffic ER line, suggesting the additional influence of sources during both seasons despite expected seasonal changes in the composition of traffic emission. In summer, the scatterplot equals (Strasbourg) or is above the traffic ER line (Paris and London) and tends to the one of evaporative emissions. This would suggest the presence of fugitive evaporative processes in addition to traffic. In winter, the scatterplot lies between the traffic ER in its upper part and the domestic wood combustion ER in its lower part. This would suggest an additional source of wood combustion for benzene ${ }^{27}$, ${ }^{28}$. Note that the observed multiform patterns are rather driven by the seasonal variability of benzene mixing ratios than the ones of toluene especially in Strasbourg, a city submitted to well-marked continental climatic conditions. For Strasbourg this is consistent with the emission inventory (Figure 1). Note also that the multiform pattern is temperature-dependent as seen in Paris and Strasbourg when color-coded with temperature (Figure S4 in Supplement Information). Toluene mixing ratios stay rather constant between both seasons. One cannot 
197 exclude that the correlation slope can be affected by photochemical processing for most 198 reactive $\operatorname{VOCs}^{21,22}$ especially in summer. When applying the nighttime and daytime filters 199 values following Borbon et al. $(2013)^{30}$, no significant difference is depicted suggesting that 200 emissions mainly control TEX concentrations (not shown here). It is consistent with 201 observations during MEGAPOLI-2010 ${ }^{30}$ in Paris. The effect of photochemistry on TEX 202 concentrations was only visible in the Paris plume explored by the French ATR-42 aircraft 203 during the MEGAPOLI campaign in the summer 2009 at a distance above $50 \mathrm{~km}$, at least, 204 from the urban center ${ }^{30 .}$.

205

206

207

208

209

210

211

212

213

214

215

216

217

The correlation slopes have been determined on a monthly basis at traffic and urban background sites. The toluene-to-benzene ERs are reported in Figure $2 \mathrm{~b}$ for Paris and Strasbourg. As expected, a clear seasonal variability is depicted on ER time series with a higher variability at urban background sites. However, both cities show an opposite pattern. In Paris, ERs are similar in winter and the urban background ER significantly increases in summer compared to the traffic ER. In Strasbourg, the summertime ERs are similar while the urban background ER decreases compared to the traffic ER in winter. Such temporal and spatial variability also suggests the potential gaining importance of summertime sources other than traffic as in Paris (evaporation) and the potential gaining importance of wintertime sources other than traffic as in Strasbourg (residential wood combustion).

Finally, seasonal scatterplots of TEX mixing ratios versus benzene mixing ratios and time series of TEX-to-benzene ER suggest a seasonal change in traffic emission composition and the potential influence of sources other than traffic to BTEX concentrations. The importance of these additional source contributions is going to be evaluated in the next section.

\section{Contribution of traffic emissions to TEX concentrations}


220 The method consists in estimating the fraction of each TEX originating from traffic emissions

221 at the urban background sites which are representative of the urban emission mixing. This

222 fraction is calculated by dividing the TEX concentration originating from traffic emissions to 223 the measured concentration. The TEX concentration originating from traffic emissions 224 ([TEX $\left.]_{\text {traffic }}\right)$ is expressed as follows:

where $[\text { tracer }]_{\text {traffic }}$ is the concentration of a traffic tracer subtracted by its regional background

227 concentration ([tracer $]_{\text {bckgd }}$ ) which could be significant for longer-lived compounds like 228 benzene ${ }^{28}$ and $\mathrm{ER}_{\text {traffic }}$ is the urban enhancement emission ratio from traffic between TEX and 229 the traffic tracer. This equation is derived from the one developed by Borbon et al. $(2003)^{21}$.

230

231

232

233

234

235

Acetylene has been commonly used as a traffic exhaust tracer ${ }^{21,32}$. However, a non-exhaust combustion source cannot be excluded especially during the winter season regarding domestic heating as for benzene ${ }^{28}$. In past studies, acetylene and ethylene have already shown significant contributions in the wood burning factor solution calculated by $\mathrm{PMF}^{27,28}$. To take into account potential additional sources to traffic and seasonal changes in their relative importance, five hydrocarbon tracers have been selected in order to derive an uncertainty of the TEX traffic fraction. These tracers include: four combustion products/tracers (ethylene, propene, acetylene and benzene) for which a wintertime domestic heating combustion source cannot be excluded and an unburned-fuel VOC (isopentane) for which a gasoline evaporation source has been demonstrated in summer ${ }^{21,3}$. In addition, source attributions for the five tracers by the AIRPARIF (Paris) and NAEI (UK) emission inventories are reported in the Supplement information (figure S8). 
242 ER $_{\text {traffic }}$ is determined from the slope of a two-sided linear regression fit between TEX at

243 traffic rush hours and the tracer measured at the traffic sites. For Paris, the determination of

244 ER $_{\text {traffic }}$ for TEX combines ERs relative to benzene at the traffic site (Auteuil) and ER of

245 benzene relative to other tracers from the Prequalif tunnel experiment (see $6^{\text {th }}$ column of

246 Table S1). While the $\mathrm{ER}_{\text {traffic }}$ from the PREQUALIF experiment was only determined during

247 the fall period (September-October 2012), it is representative of the average of expected

248 monthly ERs, the maxima and minima usually being observed in summer and winter (see

249 discussion below). While the contribution at the traffic site of additional sources can be

250 neglected, some seasonal changes in vehicle fuel composition can be expected as a result of

251 seasonal changes in fuel composition regulation and temperature-dependent evaporative

252 emissions. $\mathrm{ER}_{\text {traffic }}$ was therefore determined on a monthly basis. $\mathrm{ER}_{\text {traffic }}$ relative to the five

253 tracers values are reported in Table S1 at the three traffic sites. The monthly variability of

254 ER $_{\text {traffic }}$ is significant showing minimum and maximum values in winter and summer,

255 respectively. Minimum values from near-traffic measurements found in the literature are also

256 reported for comparison. All TEX are highly correlated with the five tracers at the traffic sites

257 with an $\mathrm{R}^{2}$ higher than 0.80 and a narrow distribution along the regression slope as an

258 evidence of the traffic origin for TEX (see the example in figure S7 for toluene versus

259 benzene at traffic sites). Values of TEX-to-benzene ER are in the same range among the three

260 cities. It should be noted that ER in Paris and London are in the upper range compared to

261 Strasbourg (only toluene-to-benzene ER reported) and other ER derived from tunnel

262 measurements in Europe. This enrichment has been first pointed out by Borbon et al. (2013)

263 and would be due to two-wheeler powered vehicles (Salameh et al., to be submitted in 2017).

264 Note that the ER relative to benzene is quite similar and the greatest variability is usually

265 observed for toluene and $(\mathrm{m}+\mathrm{p})$-xylenes. Values of ER of TEX relative to other tracers are

266 also consistent between Paris and London. 
267 [tracer $]_{\text {bckgd }}$ is determined on an hourly basis and is derived from a linear interpolation of 268 minimum concentrations observed over a 4-day period between 2008 and 2013. The method 269 was validated by comparing the time series of interpolated background concentrations to the 270 ones observed at European rural sites in the frame of the EMEP monitoring network and 271 extracted from the EBAS database (http://ebas.nilu.no). VOC data collected twice a week is 272 available from 2008 to 2013 during a 4-hour sampling by canisters. For France, two rural sites 273 have been selected: La Tardière (LT, Western France) and Peyrusse-Vieille (PV, Southern 274 France $)^{20}$. As an example, a comparison is provided on Figures S5 and S6 in the Supplement 275 Information for the five tracers for Paris and Strasbourg. Except for some periods when local 276 influences at the rural areas cannot be excluded, especially under a continental influence and 277 analytical uncertainties, the time series of interpolated urban background minimum 278 concentrations are consistent with the ones at rural background sites. Median ratios between 279 calculated backgrounds and the ones at Peyrusse-Vieille and La Tardière equal 1.25 and 0.76, 280 respectively.

In Figure 3, we have compared the average mixing ratios derived from the traffic $\left(\mathrm{ER}_{\text {trafic }} \times[\right.$ tracer $\left.]\right)$ and background $\left([\mathrm{TEX}]_{\mathrm{bkgd}}\right)$ terms to the observed mixing ratios in the case of toluene at the three urban background sites. TEX background concentration was determined following the 4-day minima interpolation method described previously for the five tracers. The summertime average contributions of traffic, background and non-traffic terms are illustrated by pie charts and the values of annual traffic contributions to measured concentrations are reported below.

Regardless of the location, toluene concentrations show the typical seasonal variability of anthropogenic VOC with maximum concentrations in winter and minimum concentrations in 
291 dominate toluene mixing ratios by explaining more than $70 \%$ of the observed concentrations.

292 Given the use of five tracers, the standard deviation of traffic fraction was estimated to be 293 within a $\pm 13-24 \%$ range. The background contribution is significant with an annual average 294 of $7 \%$ in Strasbourg, $16 \%$ in London and $20 \%$ in Paris. Contrary to other mono-aromatics, a 295 high background level was found for toluene in Paris exceeding by almost $0.40 \mathrm{ppb}$ the rural 296 ones. We suspect the background concentration being overestimated by our method. We 297 cannot exclude that the estimated background include a non-traffic source term. However, 298 when substracting the background term, traffic emissions explains more than $90 \%$ of toluene 299 concentrations. In summer, the traffic contribution remains higher than 58\% (Paris, 2013) and 300 higher than $78 \%$ without accounting for the background term. This is not significantly different 301 from the annual contribution. The expected additional contribution of summertime evaporative 302 sources (like gasoline evaporation from Figure 2) is not depicted. Firstly, our apportionment 303 method (see equation 1) takes into account the seasonal variability of traffic emission 304 composition by the determination and the use of monthly ER values (Table S1). Secondly, this 305 suggests that the shape of the scatterplots reported in Figure 2a is driven rather by the seasonal 306 change of traffic emission composition and additional non-traffic sources in winter like 307 domestic combustion for the tracers. It should be noted that the sum of the traffic and 308 background terms in winter is usually higher than observed concentrations, indicating that 309 combustion sources other than traffic contribute to the tracer mixing ratios. The strongest 310 evidence is seen at the continental background site of Strasbourg. When only considering 311 isopentane as a traffic tracer in winter in Strasbourg, the traffic contribution falls by $20 \%$ compared to the one by combustion tracers but remains above a 50\%-contribution (not shown here). However, our results suggest that the traffic source contribution has decreased by $31 \%$ in Paris over the last six years. This trend is not depicted in Strasbourg and London. Further analysis for the years following 2013 should be performed to confirm this trend. On an annual 
basis, these results are consistent with emission inventories in the megacities of Paris and London (Figure 1) even if the observed traffic contribution is higher. For Strasbourg, the emission inventory only allocates $10 \%$ of toluene emissions to traffic (Figure 1) which would be largely underestimated as suggested by our results.

Annual values and summertime pie charts of the traffic contribution are compiled for all other mono-aromatic compounds in Table 2. The values of summertime traffic contribution are usually within the standard deviation of the annual ones. While the split limit between traffic and non-traffic contribution is more tenuous for $>\mathrm{C}_{7}$-aromatics (e.g. $(\mathrm{m}+\mathrm{p})$-xylenes in Strasbourg), traffic emissions would still dominate the concentrations of $>\mathrm{C}_{7}$-aromatics. The summertime (and annual) contribution of traffic is usually higher than $60 \%$ and up to $96 \%$ over the last six years in the three cities. One exception is the 2013-contribution with a $43 \%$-value to o-xylene concentrations in London and a 46\%-contribution for $(\mathrm{m}+\mathrm{p})$-xylenes in Strasbourg in 2009. In London, the summertime traffic contribution to o-xylene concentrations has decreased from $86 \%$ to $43 \%$. The decreasing trend for $(\mathrm{m}+\mathrm{p})$-xylenes in London is surprisingly not as clear as for o-xylene. This finding is consistent with the observed change at Eltham in the o-xylene-to- $(\mathrm{m}+\mathrm{p})$-xylenes when looking at the shape of the scatterplot (not shown here) Further analysis should be performed after 2013 to confirm. These results are qualitatively consistent with emission inventories for ethylbenzene but usually disagree for xylenes in the French cities of Paris and Strasbourg, for which the solvent use dominates by far their emissions (Figure 1).

In Paris, the traffic contribution for the year 2010 is compared to the one extracted from a PMF source-receptor study by Baudic et al. ${ }^{28}$ for the same reference year. Baudic and co-workers ${ }^{28}$ performed a PMF analysis on a one-year hourly VOC dataset, including the NMHC data used here. They found an optimized solution of 6 factors, including a Motor Vehicle Exhaust, an 
Evaporative Sources and a Solvent Use factor. The Evaporative Source factor is related to gasoline evaporation as well as other fossil fuel storage and distribution activities. The contribution of BTEX to this factor being less than $1 \%$, the following discussion will only focus on the two other factors. From the fraction of each TEX in the factor profiles and the modelled concentration of each factor, the modelled contribution of the Motor Vehicle Exhaust (MVE) Factor was calculated to TEX concentrations predicted by the PMF model. This comparison should be interpreted with caution since (i) the MVE contribution is calculated on TEX predicted concentrations (ii) PMF source profiles are assumed to be constant during the whole year in the PMF calculation (iii) assumptions regarding factor identification. For the latter, factor identification is consolidated by comparing to near-source measurement profiles and independent source tracer such as $\mathrm{BC}_{\mathrm{ff}}$ (Black Carbon from fossil fuel combustion) for the MVE factor. Regarding item (i), note that observed concentrations are $30 \%$ higher than the ones predicted by the PMF 6-factor solutions for toluene and higher than $20 \%$ for $\mathrm{C}_{8^{-}}$ aromatics. Regarding item (ii) ER calculations have shown a clear seasonal variability implying that traffic emission profiles change during the year. PMF allocates $39 \% \pm 13 \%$ of Motor Vehicle Exhaust and $38 \% \pm 17 \%$ to Solvent Use to toluene concentrations while our study allocates $79 \% \pm 19 \%$ to traffic emissions on an annual basis. For $\mathrm{C}_{8}$-aromatics, PMF allocates $39 \% \pm 16 \%$ to Solvent Use and $36 \% \pm 13 \%$ to MVE against $72 \% \pm 24 \%$ to traffic emissions in our study. While traffic emissions include both exhaust and gasoline evaporative losses in our study, the approach developed here shows a higher contribution of traffic source to aromatic emissions for all $\geq \mathrm{C}_{7}$ aromatics than the one suggested by the PMF. Given the limitations of such a comparison (see above), it is expected that the factor-of-two difference of traffic is the upper limit and should be lower and within the uncertainties of both approaches. Except the study by Baudic (2016), there is almost no recent study reporting on VOC source apportionment in European urban areas for a direct comparison. As VOC emission regulation 
365 is decided at European level, we expect our results to be extrapolated to other tertiary

366 metropolitan areas in Europe which have the same anthropogenic activity pattern. However, at

367 lower latitude cities like the ones on the Mediterranean border, higher ambient temperature 368 should favor the contribution of evaporative losses.

\section{Acknowledgements}

Nadine Locoge, Stéphane Sauvage and Antoine Waked from IMT Lille Douai (France) were very helpful for consolidating VOC observations from AASQA and EMEP stations. Stéphane Bonneau and Alexandre Probellet at AIRPARIF and ASPA, respectively, were efficient in providing the NMHC and BTEX original data from the AASQA. The authors would like to thank Roy Harrison, Dick Derwent and Sean Beevers (Kings College) for the information they provided on the status of VOC emission inventories for the UK and London. Thérèse Salameh benefitted from an Ile de France - R2DS postdoctoral grant (2015-2016) and Anne Boynard benefitted from a financial support from CNES. The authors would like to thank Cathy Clerbaux for allowing the preparation of the present work.

Supplement Information Available. Time series of TEX concentrations in the three cities. Source contributions to TEX emissions from emission inventories. Description of the sites and analytical devices for VOC measurements. Determination of the toluene-to-benzene ER representative of traffic, wood combustion and gasoline evaporation emissions. Time series of hydrocarbon tracer concentrations at urban and rural sites for background determination. BTEX average concentrations at traffic and urban background sites and $\mathrm{ER}_{\text {traffic }}$ used in source apportionment calculation. Correlation plots for the determination of $\mathrm{ER}_{\text {traffic }}$. Source contributions to tracer emissions. 


\section{References}

389

390

391

392

393

394

395

396

397

398

399

400

401

402

403

404

405

406

407

408

409

410

411

412

413

414

415

416

417

418

419

420

421

422

423

424

425

426

427

428

429

430

431

432

[1] Gros, V., Gaimoz, C., Herrmann, F., Custer, T., Williams, J., Bonsang, B., Sauvage, S., Locoge, N., D'Argouges, O., Sarda-Estève, R., Sciare, J., Volatile organic compounds sources in Paris in spring 2007. Part I: qualitative analysis, Environ. Chem., 2011, Vol. 8, N¹, pp 7490

[2] Boynard, A., Borbon, A., Leonardis, T., Barletta, B., Meinardi, S., Blake, D.R., Locoge, N., Spatial and seasonal variability of measured anthropogenic non-methane hydrocarbons in urban atmospheres : Implication on emission ratios. Atmos. Environ., 82, 2014 pp.258-267. $\leq 10.1016 /$ j.atmosenv.2013.09.039>,

[3] Salameh, T., Sauvage, S., Afif, C., Borbon A., Leonardis, T., Brioude, J., Waked, A., Locoge, N., Exploring the seasonal NMHC distribution in an urban area of the Middle East during ECOCEM campaigns: very high loadings dominated by local emissions and dynamics, Environ. Chem., 2015, 12(3), 316-328, http://dx.doi.org/10.1071/EN14154.

[4] Dominutti P.A., Nogueira, T., Borbon, A., de Fatima Andrade, M., Fornaro, A., One-year of NMHCs hourly observations in São Paulo megacity: meteorological and traffic emissions effects in a large ethanol burning context, Atmos. Environ., 2016, 142, 371-382, http://dx.doi.org/10.1016/j.atmosenv.2016.08.008.

[5] Wang, G., Cheng, S., Wei, W., Zhou, Y., Yao, S., Zhang, H., Characteristics and source apportionment of VOCs in the suburban area of Beijing, China, Air. Poll. Res. 2016, 7(4), 711-724, http://dx.doi.org/10.1016/j.apr.2016.03.006.

[6] Waked, A., Sauvage, S., Borbon, A., Gauduin, J., Pallares, C., Vagnot, MP., Léonardis, T., Locoge, N., Multi-year levels and trends of non-methane hydrocarbon concentrations observed in ambient air in France, Atmos. Environ., 2016, 263-275, 141, https://doi.org/10.1016/j.atmosenv.2016.06.059.

[7] Cocheo, V., Sacco, P., Boaretto, C., De Saeger, E., Perez Ballesta, P., Skov, H., Goelen, E., Gonzalez, N., Baeza Caracena, A., Urban benzene and population exposure, Nature Brief Communication, 2000, vol. 404,

[8] AIRPARIF, Air quality annual report Surveillance et information sur la qualité de l'air en Ile de France en 2015, April 2016, 93 pages, http://www.airparif.asso.fr/_pdf/publications/bilan-2015.pdf

[9] Carter W.P.L., Development of ozone reactivity scales for volatile organic compounds. Journal of Air and Waste Management Association, 1994, 44, pp. 881-899.

[10] Carter W.P.L., Updated Maximum Incremental Reactivity scale for regulatory applications, Air Pollution Ressource Center and College of Engineering, Center for Environmental Research and Technology, University of California, Preliminary Report, 1998, Contract $\mathrm{n}^{\circ}$ 95-308, Riverside, USA, 73 p. 
[11] Deguillaume, L., Beekmann, M., Derognat, C., Uncertainty evaluation of ozone production and its sensitivity to emission changes over the Ile-de-France region during summer periods, J. Geophys. Res. Atmos., 2008, 113, 1-13, doi: 10.1029/2007JD009081.

[12] Odum, J. R., Jungkamp, T. P. W., Griffin, R. J., Flagan, R. C. and Seinfeld, J. H.: The Atmospheric Aerosol-Forming Potential of Whole Gasoline Vapor, Science, 1997, 276(5309), 96-99, doi:10.1126/science.276.5309.96.

[13] Ng, N. L., Kroll, J. H., Chan, A. W. H., Chabra, P. S., Flagan, R. C. and Seinfeld, J. H.: Secondary organic aerosol formation from m-xylene, toluene, and benzene, Atmos. Chem. Phys., 2007, 7(14), 3909-3922, doi:10.5194/acp-7-3909-2007.

[14] Lee, A., Goldstein, A. H., Kroll, J. H., Ng, N. L., Varutbangkul, V., Flagan, R. C. and Seinfeld, J. H.: Gas-phase products and secondary aerosol yields from the photooxidation of 16 different terpenes, J. Geophys. Res., 2006, 111(D17), D17305, doi:10.1029/2006JD007050.

[15] Ait-Helal, W., Borbon, A., Sauvage, S., de Gouw, J. A., Colomb, A., Gros, V., Freutel, F., Crippa, M., Afif, C., Baltensperger, U., Beekmann, M., Doussin, J.-F., Durand-Jolibois, R., I. Fronval, , N. Grand, N, Leonardis, T., Lopez, M., Michoud, V., Miet, K., Perrier, S., Prévôt, A. S. H., Schneider, J., Siour, G., Zapf, P., and Locoge, N., Volatile and intermediate volatility organic compounds in suburban Paris: variability, origin and importance for SOA formation, Atmos. Chem. Phys., 2014, 14, 10439-10464, doi:10.5194/acp-14-10439-2014

[16] Zhao, Y., Hennigan, C. J., May, A. A., Tkacik, D. S, de Gouw, J. A., Gilman, J. B., ,Kuster, W., Borbon, A., and Robinson, A.L., Intermediate-volatility organic compounds: a large source of secondary organic aerosol, Env. Sc. Tech., 2014, 48(23) Pages: 13743-13750, DOI: $10.1021 /$ es5035188.

[17] Molteni, U., Bianchi, F., Klein, F., El Haddad, I., Frege, C., Rossi, MJ., Dommen, J., Baltensperger, U., Formation of highly oxygenated organic molecules from aromatic compounds. Atmos. Chem. Phys. Discuss., 2016, doi: 10.5194/acp-2016-1126, under review.

[18] von Schneidemesser, E., Monks, P. S. and Plass-Duelmer, C., Global comparison of VOC and CO observations in urban areas, Atmos. Environ., 2010, 44(39), 5053-5064, doi:10.1016/j.atmosenv.2010.09.010.

[19] Warneke, C., de Gouw, J.A., Holloway, J.S., Peischl, J., Ryerson, T.B., Atlas, E., Blake, D., Trainer, M., Parrish, D.D., Multiyear trends in volatile organic compounds in Los Angeles, California: Five decades of decreasing emissions, J. Geophys. Res. Atmospheres, 2012, 117, D00V17, doi:10.1029/2012JD017899

[20] Sauvage, S., Plaisance, H., Locoge, N., Wroblewski, A., Coddeville, P., Galloo, J.C., Long term measurement and source apportionment of non-methane hydrocarbons in three French rural areas, Atmos. Environ., 2009, 43, 2430-2441. 
[21] Borbon A., H. Fontaine, N. Locoge, M. Veillerot, J.C. Galloo, Developing receptororiented methods for non-methane hydrocarbon characterisation in urban air. Part II: source apportionment, Atmos. Environ., 2003, 37 4065-4076.

[22] Warneke, C S., McKeen, A., de Gouw, J.A., Goldan, P.D., Kuster, W. C., Holloway, J.S., Williams, E.J., Lerner, B. M, Parrish, D. D., Trainer, M., Fehsenfeld, F.C., Kato, S., Atlas, E. L., Baker, A., and Blake, D. R., Determination of urban volatile organic compound emission ratios and comparison with an emissions database. J. Geophys. Res., 2007, 112, D10S47. http://dx.doi.org/10.1029/2006JD007930.

[23] Coll, I., Rousseau, C., Barletta, B., Meinardi, S., and Blake, D.R., Evaluation of an urban NMHC emission inventory by measurements and impact on CTM results, Atmos. Env., 2010, 44(31), 3843-3855.

[24] Gaimoz, C., Sauvage, S., Gros, V., Herrmann, F., Williams, J., Locoge, N., Perrussel, O., Bonsang, B., d'Argouges, O., Sarda-Estève, R., Sciare, J., 2011. Volatile Organic Compounds Sources in Paris in Spring 2007. Part II: Source Apportionment Using Positive Matrix Factorisation. Environ. Chem., 2011, 8, no. 1, 91-103.

[25] Salameh, T., Borbon, A., Afif, C., Sauvage, S., Leonardis, T., Gaimoz, C., and Locoge, N.: Composition of gaseous organic carbon during ECOCEM in Beirut, Lebanon: new observational constraints for VOC anthropogenic emission evaluation in the Middle East, Atmos. Chem. Phys., 2017, 17, 193-209, doi:10.5194/acp-17-193-2017, 2017.

[26] Niedojadlo, A., Becker, K. H., Kurtenbach, R., Wiesen, P., The contribution of traffic and solvent use to the total NMVOC emission in a German city derived from measurements and CMB modelling, Atmos. Environ., 2007, 41, 7108. doi:10.1016/J.ATMOSENV.

[27] Lanz, V. A., Hueglin, C., Buchmann, B., Hill, M., Locher, R., Staehelin, J. and Reimann, S.: Receptor modeling of C2-C7 hydrocarbon sources at an urban background site in Zurich, Switzerland: changes between 1993-1994 and 2005-2006, Atmos. Chem. Phys., 2008, 8(9), 2313-2332, doi:10.5194/acp-8-2313-2008.

[28] Baudic, A., Gros, V., Sauvage, S., Locoge, N., Sanchez, O., Sarda-Estève, R., Kalogridis, C., Petit, J.-E., Bonnaire, N., Baisnée, D., Favez, O., Albinet, A., Sciare, J., and Bonsang, B.: Seasonal variability and source apportionment of volatile organic compounds (VOCs) in the Paris megacity (France), Atmos. Chem. Phys., 2016, 16, 11961-11989, doi:10.5194/acp-1611961-2016

[29] Dollard, G. J., Dumitrean, P., Telling, S., Dixon, J. and Derwent, R. G., Observed trends in ambient concentrations of C2-C8 hydrocarbons in the United Kingdom over the period from 1993 to 2004, Atmos. Environ., 2007, 41, 2559-2569.

[30] Borbon, A., Gilman, J.B., Kuster, W. C., Grand, N., Chevaillier, S., Colomb, A., Dolgorouky,C., Gros, V., Lopez, M., Sarda-Esteve, R., Holloway, J., Stutz, J., Perrussel, O., Petetin, H., McKeen, S., Beekmann, M., Warneke, C., Parrish, D.D., and de Gouw, J., Emission ratios of anthropogenic VOC in northern mid-latitude megacities: observations vs. 
521 emission inventories in Los Angeles and Paris. J. Geophys. Res., 2013, vol. 118, 2041-2057, 522 doi:10.1002/jgrd.50059

[31] Yuan, B., Shao, M., Lu, S., Wang, B., Source profiles of volatile organic compounds associated with solvent use in Beijing, China, Atmos. Environ., 2010, 44, 1919-1926.

526

527

528

[32] Salameh, T., Afif, C., Sauvage, S., Borbon, A., and Locoge, N.: Speciation of NonMethane Hydrocarbons (NMHC) from anthropogenic sources in Beirut, Lebanon, Environ. 529

530

531 

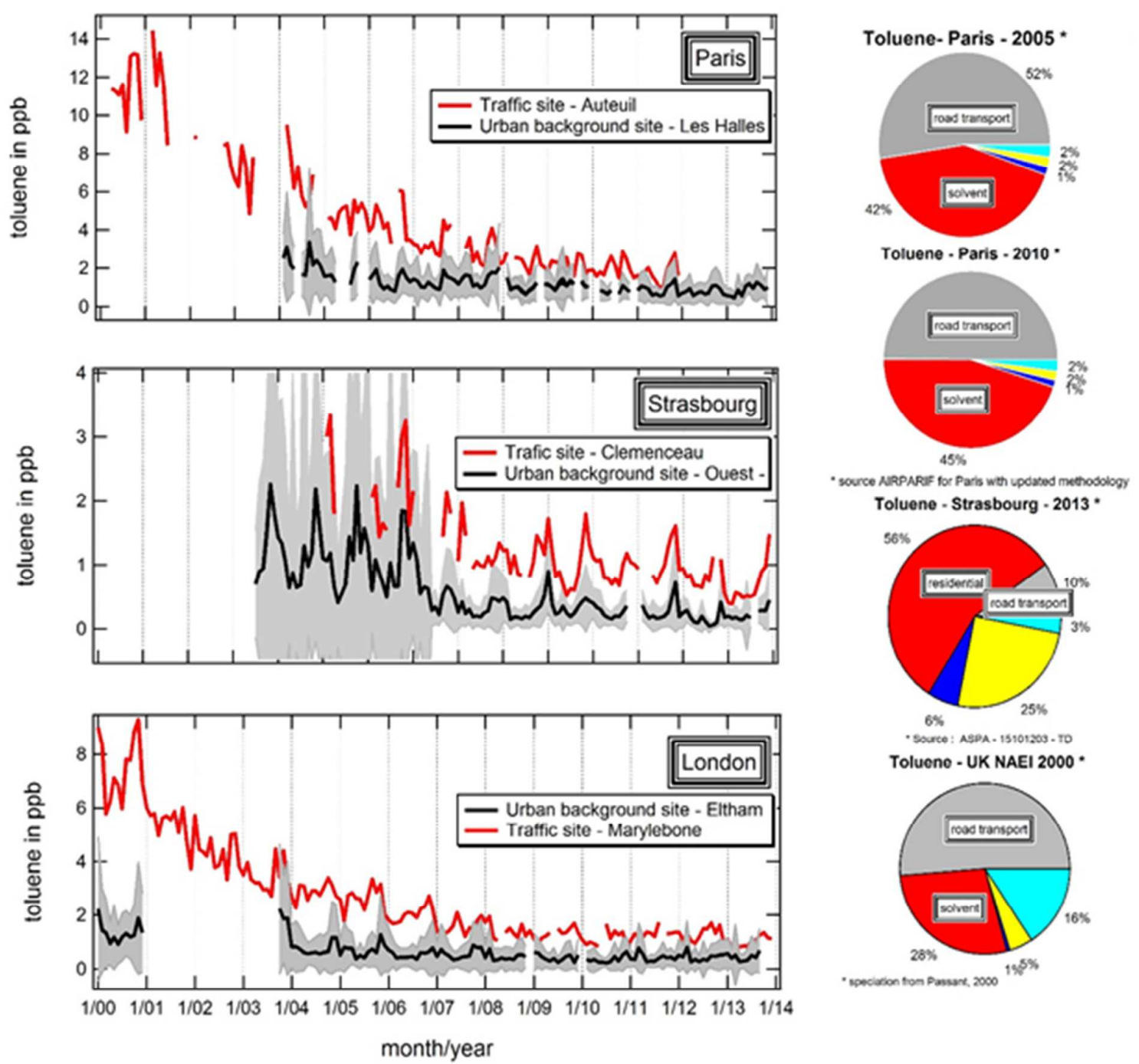

Figure 1: Time series of toluene monthly mean concentrations in Paris, Strasbourg and London at traffic and urban background sites since 2000 (left panel). The grey shaded area corresponds to the standard deviation of the monthly mean concentrations at the background sites. Associated apportioned emissions of toluene extracted from local emission inventories are reported on right panel (grey: road transport ; red: solvent use or residential for Strasbourg; dark blue: extraction and distribution of fossil fuel; yellow: non-industrial combustion and industrial activities for Strasbourg; light blue: other activities. 
a)
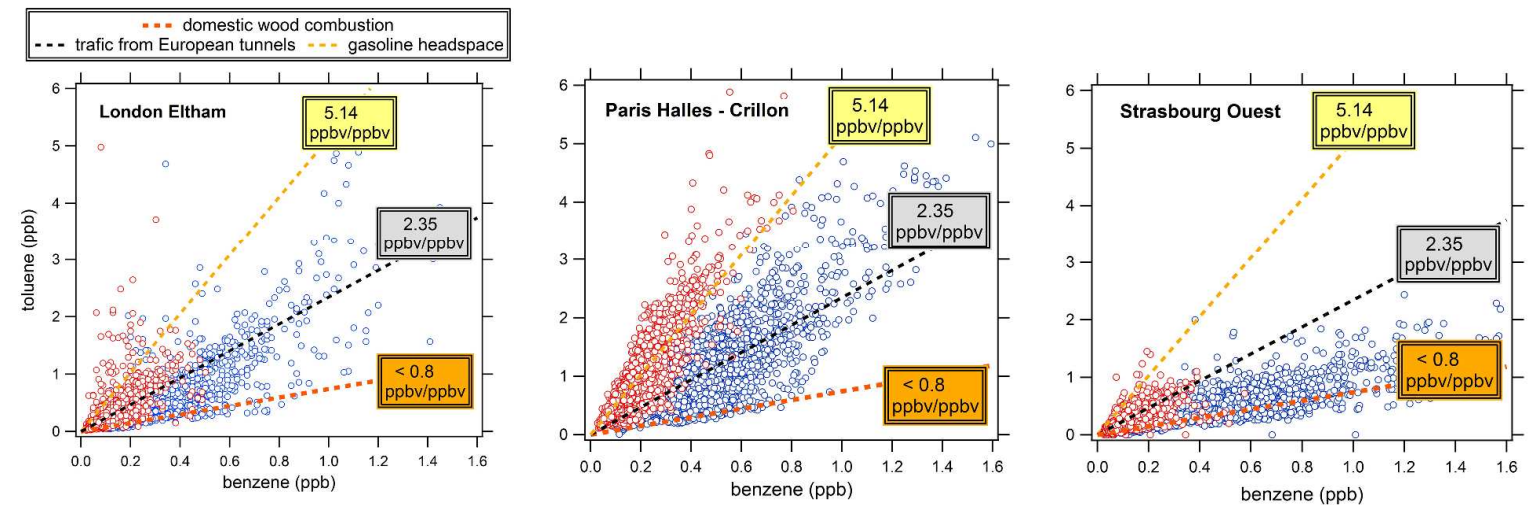

547

b)

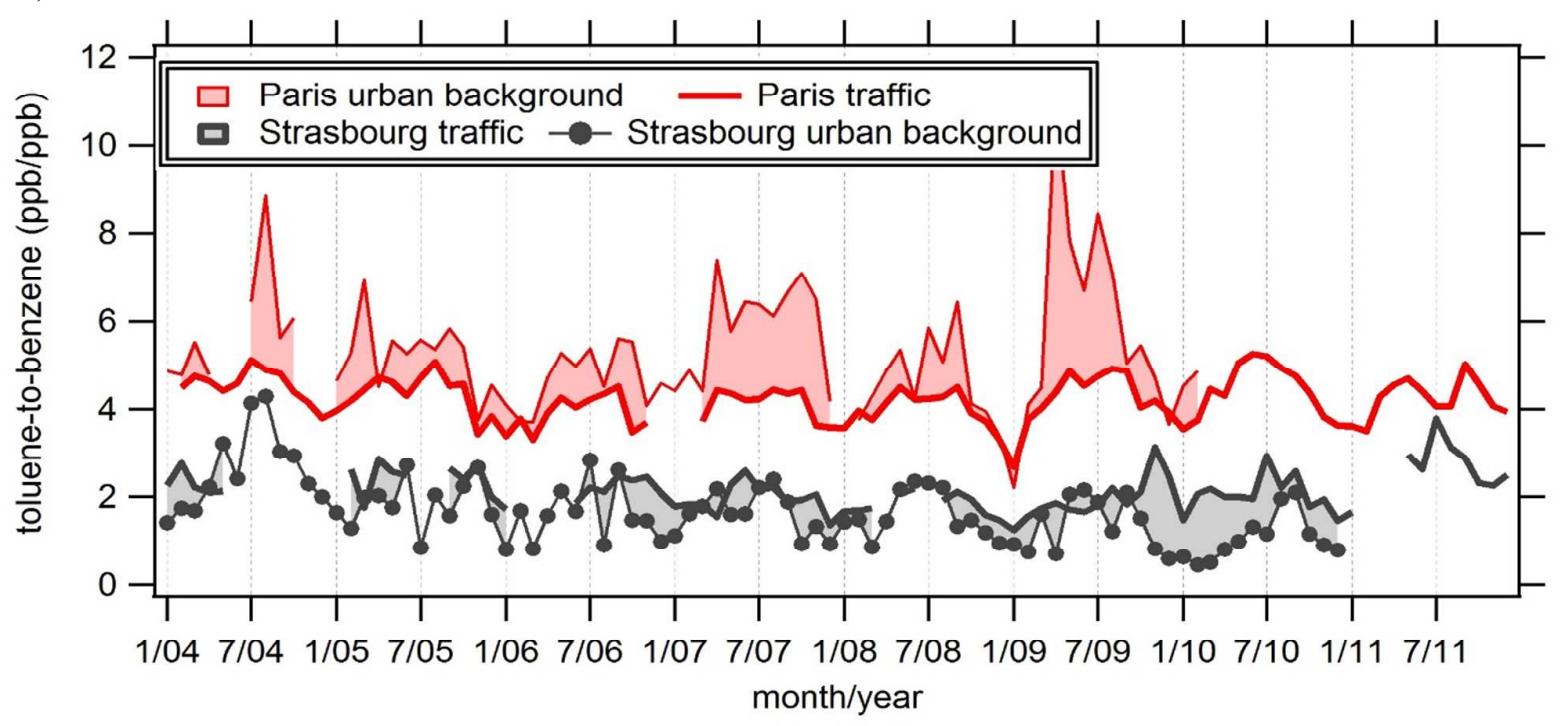

548

549

550

551

552

553

554

555

556

Figure 2: (a) Scatterplots of toluene versus benzene concentrations in January (blue) and July (red) months at London, Paris and Strasbourg urban background sites (2008-2013). Dotted lines are average toluene-to-benzene ERs representative of traffic (Aït-Helal et al., 2015), domestic wood combustion (Gaeggeller et al. 2008; Evtyugina et al., 2014; Baudic et al., 2016) and gasoline evaporation emissions (Salameh et al., 2017). (b) Time series of monthly toluene-to-benzene urban enchancement ratios (ER) derived from the slopes of correlation plots for Paris and Strasbourg at traffic and urban background sites 

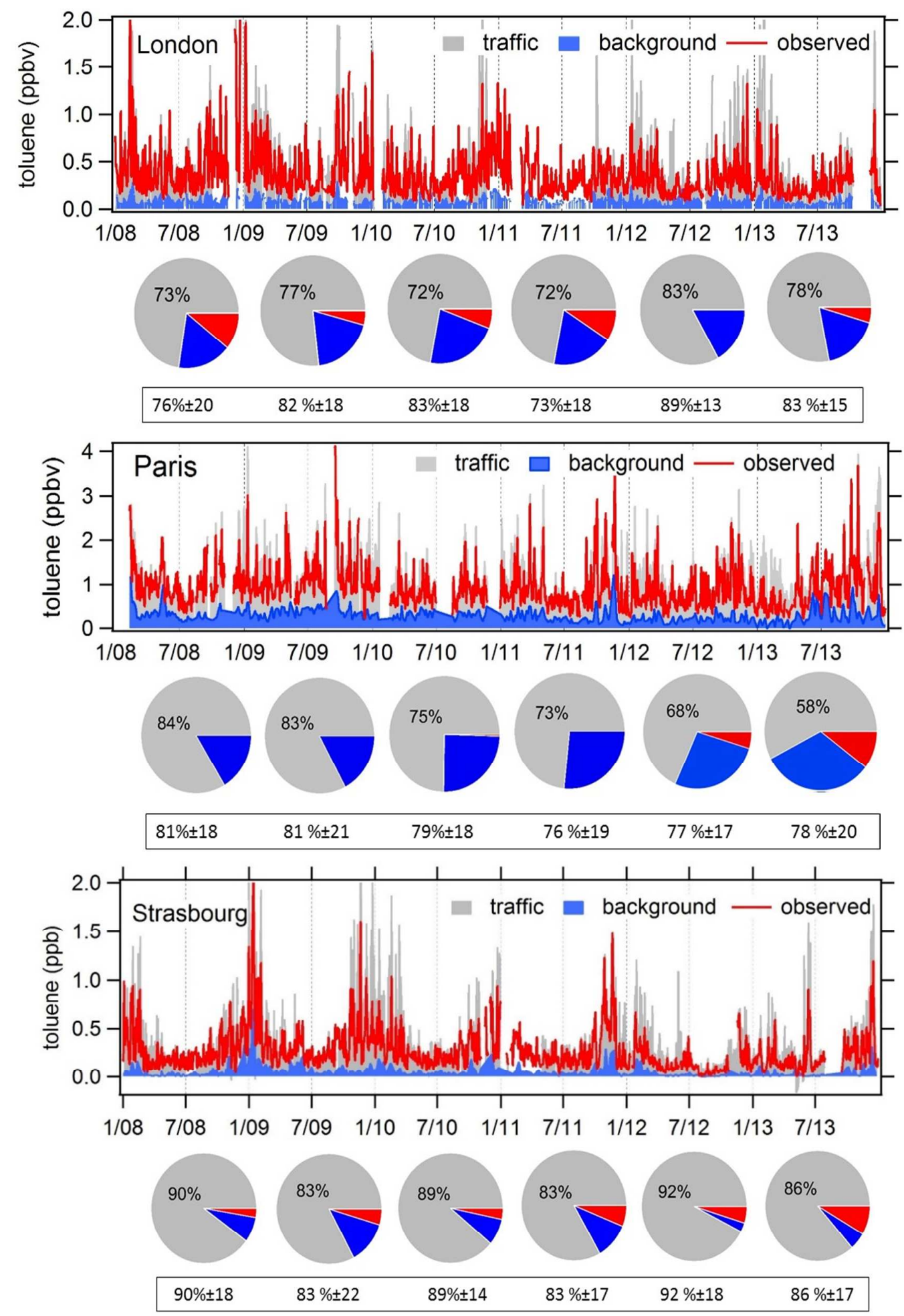

Figure 3 : Time series of toluene concentration terms in Paris, Strasbourg and London between 2008 and 2013. Data are smoothed a 30-day basis. Below time series, pie charts represent the average summertime (JJA) percent contribution of the traffic term (in grey), 
605 background term (in blue) and non-traffic term (in red) to toluene concentrations. Framed 606 numbers are the annual average contribution of traffic and its standard deviation.

607 
Table 2:

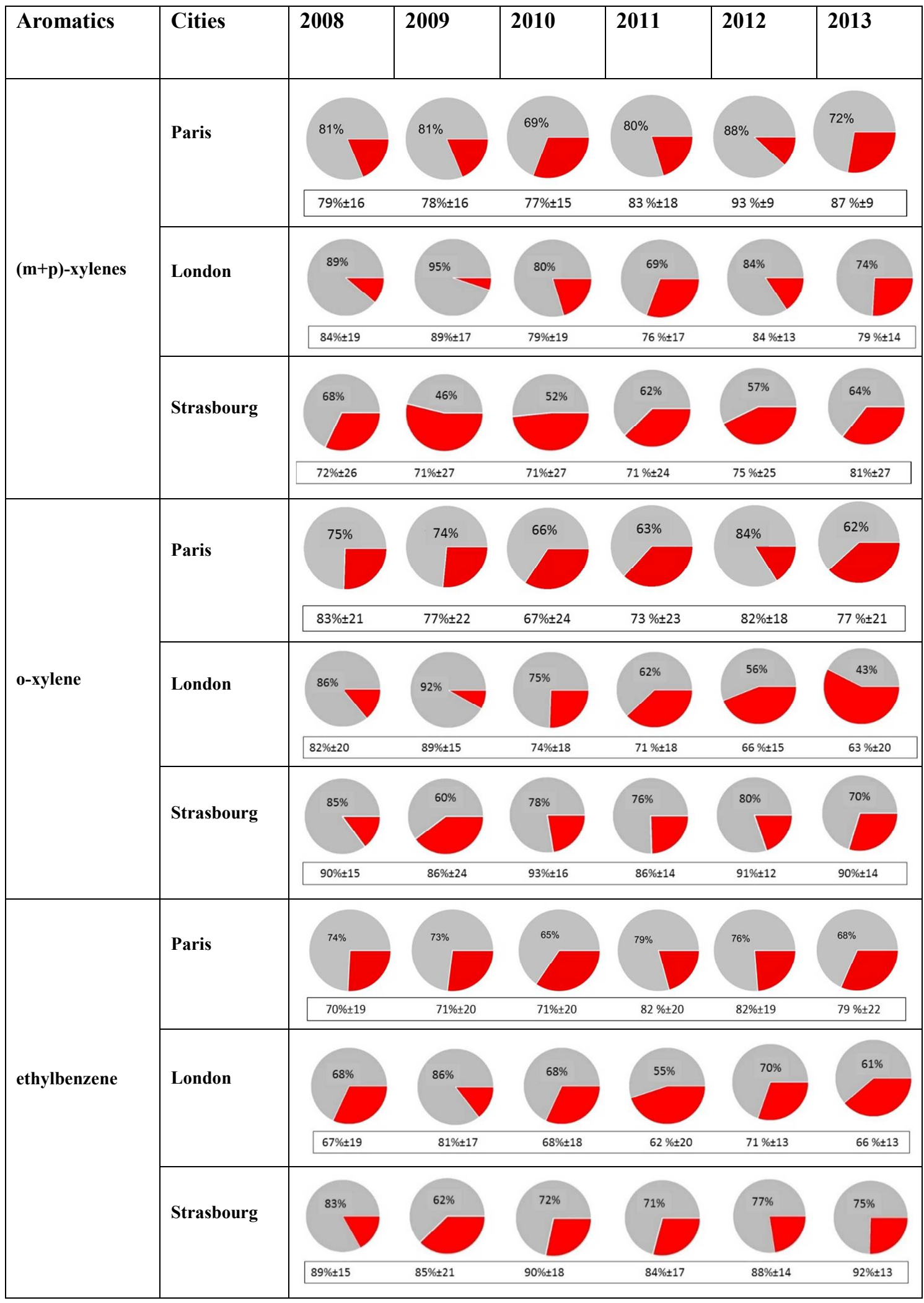


609 Table 2: Mean contribution in \% of traffic emissions (in grey) to $(\mathrm{m}+\mathrm{p})$-xylenes, $\mathrm{o}-\mathrm{xylene}$ and 610 ethylbenzene concentrations in summer (JJA) in Paris, London and Strasbourg between 2008 611 and 2013. Non-traffic contribution (in red) includes the background. Framed numbers 612

613

614

615

616 represent the annual mean contribution of traffic emissions

Table 1: VOC data used for this study

\begin{tabular}{|c|c|c|c|c|c|c|c|}
\hline Location & Site & Type & Coord. & Network & Period & $\%$ missing data & Reference \\
\hline \multirow[t]{2}{*}{ London } & Marylebone Road & Traffic & $51.52 \mathrm{~N},-0.1546 \mathrm{~W}$ & Hydrocarbon Automatic Network & $2008-2013$ & $23 \%$ & Dollard et al., 2007 \\
\hline & Eltham & Urban & $51.45 \mathrm{~N}, 0.071 \mathrm{E}$ & Hydrocarbon Automatic Network & $2008-2013$ & $19 \%$ & Dollard et al., 2007 \\
\hline \multirow[t]{3}{*}{ Paris } & Auteuil & Traffic & $48.85 \mathrm{~N} 2.25 \mathrm{E}$ & AIRPARIF & $2008-2011$ & $24 \%$ & \\
\hline & Les Halles - Crillon & Urban & $48.86 \mathrm{~N} 2.34 \mathrm{E}$ & AIRPARIF & $2008-2013$ & $6 \%$ & Waked et al., 2016 \\
\hline & Guy Moquet tunnel & Tunnel & $48.01 \mathrm{~N} 2.65 \mathrm{E}$ & PREQUALIF experiment & Sept-Oct. 2012 & $2 \%$ & Baudic et al., 2016 \\
\hline \multirow[t]{2}{*}{ Strasbourg } & Clémenceau & Traffic & $48.35 \mathrm{~N} 7.44 \mathrm{E}$ & ASPA & $2008-2013$ & $3 \%$ & \\
\hline & Strasbourg Ouest & Urban & $48.36 \mathrm{~N} 7.42 \mathrm{E}$ & ASPA & $2008-2013$ & $16 \%$ & Boynard et al., 2014 \\
\hline
\end{tabular}

617

618

619

620 